\title{
PALAEOEPIDEMIOLOGY, LITERACY, AND MEDICAL TRADITION AMONG NECROPOLIS WORKMEN IN NEW KINGDOM EGYPT
}

by

\author{
R. L. MILLER *
}

We are fortunate in having a number of sources for reconstructing the epidemiology of occupational diseases in pharaonic Egypt and the religious, magical, and medical means of treatment available to workmen engaged in various projects and tasks. In addition to the inscriptions which the leaders and personnel of official expeditions often left in the desert, ${ }^{1}$ we have a rich collection of records and monuments from the community of workmen at Deir el Medina, which give an indication of the number of working days lost through sickness, ${ }^{2}$ the accidents and health problems the workers suffered from, and even the means of magical, ritual, and medical treatment they had at their disposal. ${ }^{3}$ From the Egyptian medical texts we have an idea of the range of health problems which were diagnosed and treated, ${ }^{4}$ and it is sometimes possible to use recent

\section{* R. L. Miller, Ph.D., 594 Main Street, Northport NY 11768, USA.}

This research was made possible by a fellowship in the history of medicine from the Wellcome Trust and the academic support provided by Darwin College, Cambridge and the Wellcome Institute for the History of Medicine, London. The critical comments of T. G. H. James on an earlier version of this article are gratefully acknowledged.

${ }^{1}$ R. Grundlach, 'Expeditionswesen', in W. Helck et al. (eds.) Lexicon der Ägyptologie, 6 vols., Wiesbaden, Harrassowitz, 1975-86 (abbreviated as $L \ddot{A}$ ), vol. 2, cols. 64-8; A. H. Gardiner, T. E. Peet, and J. Cerný, The inscriptions of Sinai, 2nd ed., 2 parts, London, Egypt Exploration Society, 1952-5; R. Anthes, Die Felsinschriften von Hatnub, Leipzig, Hinrichs'sche, 1928.

2 J. J. Janssen, 'Absence from work by the necropolis workmen at Thebes', Stud. altägyp. Kult., 1980, 8: 127-52, see pp. 134-7. In the year 40 of Ramesses II, c. 1258 BC, 37 ordinary workmen, not counting officials and foremen, were employed on the king's tomb. According to Janssen's interpretation of ostracon BM 5634, which covers 280 days of this year, only 70 of these days appear to have been working days (ibid., p. 134). Illness, the most frequently given reason for absence from work, occurs in about 100 cases (ibid., p. 135). This would mean that, out of the working days recorded, about 4 per cent were lost due to sickness, a slightly higher rate than that recorded by R. B. Buzzard and W. J. Shaw, 'An analysis of absence under a scheme of paid sick leave', Br. J. ind. Med., 1952, 9: 282-95.

${ }^{3} \mathrm{D}$. Valbelle, "les ouvriers de la tombe»: Deir el-Médineh à l'époque ramesside, Cairo, Institut Français d'Archéologie Orientale du Caire, 1985, pp. 127-8, 284-6, 331.

${ }^{4}$ While it may only reflect the accidents of preservation in a desert climate, I find it interesting that the earliest medical texts discovered to date, which are concerned with midwifery and veterinary medicine, were found associated with the building project and workmen's settlement at Kahun (F. Ll. Griffith, 'A medical papyrus from Egypt', Br. med. J., 1893, i: 1172-4; idem, Hieratic papyri from Kahun and Gurob, 2 vols., London, Quaritch, 1898, vol. 1, pp. 5-14, vol. 2, pls. 5-7; see also the recent discussion of this text and translation of one prescription by S. Quirke, 'Writing and literature', in J. Bourriau, Pharaohs and mortals: Egyptian art in the Middle Kingdom, Cambridge University Press, 1988, pp. 83-4). A rich corpus of New Kingdom medical literature is also available, although a systematic treatment of it is still lacking. See, e.g., translation by F. Jonckheere, Le Papyrus médical Chester Beatty, Brussels, Fondation Égyptologique Reine Élisabeth, 1947; J. H. Breasted, The Edwin Smith Surgical Papyrus, 2 vols., University of Chicago Press, 
biomedical techniques to shed new light on ancient epidemiology and pathology. ${ }^{5}$

What was the extent of the medical traditions current among skilled workmen? The best known and best documented community of workmen in ancient Egypt are the tomb cutters, sculptors, and painters who lived in Deir el Medina and worked on the royal tombs in the Valley of the Kings west of Thebes. ${ }^{6}$ Before dealing with their health service and medical traditions and how these were probably related to the specific occupational health problems encountered by this privileged group of skilled craftsmen, we should first consider the evidence for occupational health risks encountered by ordinary Egyptian workmen and farmers.

\section{CORVEE LABOUR, PUBLIC HEALTH, AND THE BEGINNINGS OF MEDICAL TRADITION}

Neither the social history nor the medical history of ancient Egypt can be understood without appreciating the significance of corvee labour. Throughout Egyptian history, massive inputs of commodities, labour, and organization were required to quarry, transport, and shape the stone needed for the construction of large funerary monuments. ${ }^{7}$ Building pyramids, mastabas, temples, and tombs simultaneously displayed the power of the gods and the king while maintaining and reinforcing the administrative and engineering infrastructure used to channel and harvest the Nile flood and to predict, transport, and redistribute the crops, livestock, and goods produced in the valley. ${ }^{8}$ The sheer scale of pharaonic hydraulic engineering

1930; for translation of parts of the Ebers, Harris, Berlin and other medical papyri see H. Grapow, H. von Deines, and W. Westendorf, Grundriss der Medizin der Alten Ägypter, 9 vols., Berlin, Akademie Verlag, 1954-73, although the selections in this series are rearranged, incomplete, and the discussion reluctant to deal with the symptoms of infectious diseases, such as schistosomiasis, which Ruffer had shown was already present during the New Kingdom (M. A. Ruffer, "Note on the presence of "bilharzia haematobia" in Egyptian mummies of the twentieth dynasty (1250-1000 BC)', Br. med. J., 1910, i: 16). Reliable translations of many medical texts are found in G. Lefebvre, Essai sur la médecine égyptienne, Paris, Presses Universitaires de France, 1956, although this suffers from an uncritical reliance on the parasitological guesswork of B. Ebbell, an often inspired interpreter and translator of the Ebers papyrus (B. Ebbell, The Papyrus Ebers, London, Oxford University Press, 1937). The absence of recent, reliable consecutive, accurately translated editions of the Egyptian medical papyri which cover the full extent of the medical practices and traditions documented there, and which take into account the diseases and pathological conditions already identified from mummies of the population they dealt with is a major lacuna in a medical history equal in extent to the time spanned by the more recent period from Herodotus to Foucault.

${ }^{5}$ R. L. Miller, 'Dqr, spinning and treatment of guinea worm in Pap. Eb. 875', J. Egyp. Arch., 1989, 75: 249-54; A. M. Deelder, R. L. Miller, N. De Jonge, and F. W. Krijger, 'Detection of schistosome antigen in mummies', Lancet, 1990, i: 724-5; D. Brothwell and A. T. Sandison (eds.), Diseases in antiquity, Springfield, Charles C. Thomas, 1967; A. R. David (ed.), Manchester Museum Mummy Project, Manchester University Press, 1979; A. Cockburn and E. Cockburn (eds.), Mummies, disease and ancient cultures, Cambridge University Press, 1980; R. Walker et al., 'Tissue identification and histologic study of six lung specimens from Egyptian mummies', Am. J. phys. Anth., 1987, 72: 43-48; S. A. Shoemaker, 'Mummies, mycobacteria, and molecular biology - the old and new', Am. Rev. respir. Dis., 1986, 134: 642-3; S. Pääbo, 'Molecular cloning of ancient Egyptian mummy DNA', Nature, 1985, 314: 644-5.

${ }^{6}$ Valbelle, op. cit., note 3 above; J. J. Janssen, Commodity prices from the Ramesside Period, Leiden, Brill, 1975; J. Cerný, A community of workmen at Thebes in the Ramesside Period, Cairo, Institut Français d'Archéologie Orientale du Caire, 1973.

${ }^{7}$ B. J. Kemp, in B. G. Trigger et al. (eds.), Ancient Egypt: a social history, Cambridge University Press, 1983, pp. 86-7.

${ }^{8}$ Ibid.; K. W. Butzer, Early hydraulic civilization in Egypt: a study in cultural ecology, University of Chicago Press, 1976; B. Menu, Recherches sur l'histoire juridique, économique et sociale de l'ancienne Egypte, Versailles, privately printed (ISBN 2-903971-01-3), 1982, pp. 165-6. 


\section{Necropolis workmen in New Kingdom Egypt}

or the energy devoted to stone cutting and transport from desert edge to building site is still impressive. According to one recent survey, "The channelling of so much of the country's resources into the building and equipping of funerary monuments . . . must have represented the single largest industry" in Egypt during the Old Kingdom and Middle Kingdom.

From an early stage in Egyptian history, there is evidence of a medical tradition associated with large-scale public projects. ${ }^{10} \mathrm{Gold}$, building stone, precious stones, and tombs were quarried by groups of workmen in expeditions numbering anywhere from a few hundred to $17,000 .{ }^{11}$ In order for an expedition to be successful, people had to be fed, housed, and kept working in hostile desert conditions which were no less severe in antiquity than they are today, and bakers, brewers, cooks, and physicians were needed. ${ }^{12}$ Inscriptions in the Sinai peninsula record the presence of Renefseneb, a $w r$ sinw, "chief physician" among the administrative personnel of a Middle Kingdom mining expedition and two members of another mining expedition with the title sinw $s \bar{a}$, "troop physician". ${ }^{13}$ Other physicians with titles suggesting they had some responsibility for the medical needs of groups of workers or soldiers are also known, ${ }^{14}$ and in the late third millennium $\mathrm{BC}$ workers at the alabaster quarries at Hatnub, east of Amarna, had the benefit of the services of Heryshefnekht, "chief priest of Sekhmet, chief magician, chief royal physician" as well as of a scribe who was "skilled in the diagnosis of disease". 15

The large scale of the public works projects which were executed would have corresponded to an equally large scale of risk to public health from inefficient administration. In dynastic Egypt, corvee labour may on occasion have led to the mobilization of up to a quarter of a million workers at a time, ${ }^{16}$ although the figures for the size of the workforce may be overestimated by modern scholars when the numbers refer to the units of daily rations required by the workforce consigned to a project rather than to the actual number of people who worked on it. ${ }^{17}$ Temporary enclosures, hnrt, were set up to house corvee labour, and the living conditions in these camps were unlikely to have been comfortable, given that the same word was used to mean "prison camp". 18

${ }^{9}$ Kemp, op. cit., note 7 above, p. 86.

${ }^{10}$ W. A. Ward, The spirit of Ancient Egypt, Beirut, Khayats, 1965, p. 224. For monuments built by physicians themselves in necropolis complexes at Saqqara, Thebes, and Amarna, see references in F. Jonckheere, Les médecins de l'Égypte pharaonique, Brussels, Fondation Egyptologique Reine Élisabeth, 1958, especially pp. 154-6.

${ }^{11}$ Gundlach, op. cit., note 1 above, col. 64.

12 Ibid., col. 66.

${ }^{13}$ Gardiner et al., op. cit., note 1 above, stele 85, pp. 92-4, pl. 23 ("chief physician Renfsonb") and stele no. 117 , p. 121, pl. 40 ("the physician and magician Akmu"); Jonckheere, op. cit., note 10 above, pp. 59, 29, 79. For sinw, "physician", see A. Erman and H. Grapow, Wörterbuch der aegyptischen Sprache, (abbreviated as $W b$.), 7 vols., Leipzig and Berlin, Hinrichs'sche and Akademie Verlag, 1926-63, III, 427, 7-15.

14 Ibid., pp. 102-3.

15 Anthes, op. cit., note 1 above, graffito 15, pp. 33-5 and graffito 12, pp. 28-31.

16 W. C. Hayes (ed.), A papyrus of the Late Middle Kingdom in the Brooklyn Museum, New York, Brooklyn Museum, 1955, p. 131.

${ }_{17}$ Menu, op. cit., note 8 above, p. 125.

$18 \mathrm{~Wb}$., III, 296, 14-16; S. Quirke, 'State and labour in the Middle Kingdom. A reconsideration of the term hnrt', Rev. d'Égyp., 1988, 39: 83-106. 


\section{R. L. Miller}

At high concentrations of population, raised mortality rates would have been a risk whenever food, water, and basic sanitation were lacking, and interruptions in supplies would have certainly occurred. Modern refugee populations in eastern Sudan, exposed to desert environmental conditions similar to those experienced by ancient Egyptians working on corvee projects in the desert, have suffered mortality rates of up to 14 per 10,000 per day, equivalent to an annual mortality rate of 51 per cent. ${ }^{19}$ While it is unlikely that the $\sin w$ or $w r \sin w$ were primarily responsible for public health on corvee projects, as living conditions and supplies would have been the responsibility of the vizier and his officials, ${ }^{20}$ the physicians would have had the opportunity to observe and record the effects of the diseases and accidents occurring among the workforce, who may well have died at the rate of 3-4 per cent per month on some occasions if mortality rates typical of the early stages of unplanned, poorly administered camps occurred. ${ }^{21}$ Efficient administration of food and water supplies could have reduced this mortality rate considerably, by around an order of magnitude, to that prevailing among already established villages and towns elsewhere in Sudan, where deaths occur at the rate of only 2 per thousand per month. ${ }^{22}$

The pharaonic administration could ill afford to lose its population at the higher rates that were possible, and took administrative measures in attempts to ensure that food, housing, and water were adequate to maintain the population assigned to corvee duties. Menu has discussed the rations allotted to corvee labour, ${ }^{23}$ estimating that

${ }^{19}$ M. J. Toole and R. J. Waldman, 'An analysis of mortality trends among refugee populations in Somalia, Sudan and Thailand', Bull. WHO, 1988, 66: 237-47. The death of half the manpower of a corvee labour force may have occurred at times under exceptionally brutal and incompetent administration. A stele of Ramesses II claims that before improvements he initiated, gold-mining expeditions to the desert lost half of their personnel due to water shortages (C. J. Eyre, 'Work and the organization of work in the New Kingdom', in M. A. Powell (ed.), Labor in the Ancient Near East, New Haven, American Oriental Society, 1987, pp. 167-221, see p. 182). A nineteenth-century witness of corvee labour reported that 20,000 workers died excavating the Mahmoudieh Canal (V. Stuart, 'Reports respecting reorganization in Egypt', Parliament. Accounts and Papers, 1882, 83: 147-94, see p. 161). During nineteenth-century AD corvee projects, half the able-bodied population was engaged in forced labour cleaning or cutting canals for 3-4 months each year during the winter. Stuart saw a new canal being cut with 40,000 men of Qena province working sunup to sunset, apart from a midday meal of bread soaked in Nile water, then sleeping on the ground without any shelter. Breakfast and supper consisted of the same food, supplied by the workers' families. Many corvee workers died under these conditions (ibid., pp. 160-1), and Stuart's estimate of 20,000 deaths during the excavation of the Mahmoudieh Canal a generation earlier in the Delta under Muhammed 'Ali could represent the loss of half the workforce of the provinces he visited; up to 400,000 workers worked for four months per year on this project, and as many as $\mathbf{1 0 0 , 0 0 0}$ workers may have died over a three-year period (A. Richards, Egypt's agricultural development, 1800-1980, Boulder, Westview, 1982, p. 23). A mortality rate of 8.3 per cent over four months, while substantial, is only two-thirds of the higher mortality rates reached during civil wars in recent years, and reflects the ability of at least some peasants to provide enough food for their own survival. Stuart suggested that rations should be provided by the government (ibid., p. 161), as was the case in dynastic Egypt (Menu, op. cit., note 8 above, pp. 127-33; W. K. Simpson, Papyrus Reisner I, Boston, Museum of Fine Arts, 1963, p. 35).

${ }^{20}$ Menu, op. cit., note 8 above, pp. 125-7.

21 Toole and Waldman, op. cit., note 19 above; Stuart, op. cit., note 19 above, pp. 160-1. A Wadi Hammamat stele records an expedition to quarry stone in the desert in the third year of Ramesses IV's reign. There were only 10 carts of supplies for 8,368 men. Although the duration of the expedition is not known, the stele records 900 deaths, a mortality rate of approximately 10-11 per cent. As the stele was erected near the end of the second month of summer, water supplies would also have been a problem (L. Christophe, 'La stèle de l'an III de Ramsès IV au Ouâdi Hammâmât (No. 12)', Bull. Inst. fr. Archéol. orient., 1949, 48: 1-38.

22 Stuart, op. cit., note 19 above, p. 239 , fig. 1.

${ }^{23}$ Menu, op. cit., note 8 above, pp. 127--33. 


\section{Necropolis workmen in New Kingdom Egypt}

approximately one kilo of bread per day was provided to the workers requisitioned for construction projects, ${ }^{24}$ with beer and occasional portions of meat also distributed ${ }^{25}$ If the food value of modern Egyptian bread approximates that of ancient Egyptian bread, the bread ration alone would have provided approximately 2,600 kilocalories per day, ${ }^{26} 30$ per cent more than the $2,000 \mathrm{Kcal} /$ day recommended by a recent handbook as a long-term maintenance ration for displaced populations. ${ }^{27}$ The surplus would have been useful to provide the additional energy needed to carry out the hard manual labour demanded by the project for which the corvee workers had been assembled, and some of the surplus ration suggested by Menu's calculations could also have been exchanged by the workers for other commodities and souvenirs. As 2,600 $\mathrm{Kcal} /$ day is twice the ration of $1,300 \mathrm{Kcal} /$ day found in one poorly-administered twentieth-century camp to be the threshold associated with increased mortality from starvation, ${ }^{28}$ it would have provided a useful cushion against interruptions in supply as well.

This evidence of care taken to provide for the welfare of workers on public projects is not surprising, although it contradicts the popular image of ancient Egypt derived in part from Greek authors. ${ }^{29}$ Before Ptolemaic times slavery in the modern sense was not found in Egypt, ${ }^{30}$ and the labour assigned to official projects had to be carefully accounted for. ${ }^{31}$ The term used to designate unskilled corvee labourers, $h s b w$, is itself derived from the root $h s b$, "to count", and shows the importance assigned to the

24 Ibid., p. 129.

25 Ibid., p. 127.

${ }^{26}$ P. L. Pellet and S. Shadarevian, Food composition tables for use in the Middle East, American University of Beirut, 1970, section 1, no. 11, khubz masri baladi.

${ }^{27}$ S. Simmonds, P. Vaughan, and S. W. Gunn, Refugee community health care, Oxford University Press, 1983 , p. $109.50 \mathrm{~g}$ of protein per day is also recommended for long term maintenance (ibid.); it is possible that the beer and meat ration supplied to corvee labour also helped to provide the protein supplements recommended under these circumstances.

${ }^{28}$ Ibid., p. 79, fig. 4.14, pp. 251-2. Rations of five $100 \mathrm{~g}$ units of bread are also recorded, although rarely (Menu, op. cit., note 8 above, p. 128). This could correspond to the $1,300 \mathrm{Kcal} /$ day starvation threshold. It remains possible that some food may also have been provided by the families of the corvee workers, as was the case a century ago (Stuart, op. cit., note 19 above, p. 160). See also G. B. Spurr, 'Nutritional status and work capacity', Am. J. phys. Anth., Suppl. 4, 1983, pp. 1-35, esp. pp. 10-12 for a recent review of this subject where agricultural labourers with $2,400 \mathrm{Kcal} /$ day and $2,693 \mathrm{Kcal} /$ day are considered on the lower end of the range of adequate nutrition, with better off workers consuming $3,000 \mathrm{Kcal} /$ day or more. $\mathrm{R}$. Ellison has estimated that rations in ancient Mesopotamia ranged from 2,880-3,600 Kcal/day in most periods, close to the 3,000 Kcal/day recommended by the United Nations Food and Agriculture Organization ('Diet in Mesopotamia: the evidence of the barley ration texts', Iraq, 1981, 43: 35-45; idem, 'Some thoughts on the diet of Mesopotamia from c. $3000-600$ BC', ibid., 1983, 45: 146-50, omitting the Akkadian figures, which are probably too high due to ancient metrological inflation using the same name for a measure of lower capacity).

${ }^{29}$ Diodorus Siculus III, 12-13; Herodotus II, 124-8. Diodorus' account is an accurate description of the conditions under which an operation intended to result in a high mortality among the penal workforce was carried out, but this description does not necessarily apply to workplace conditions in earlier periods. The influence of cinema in reinforcing the harsh image of ancient Egyptian workplaces should not be underestimated. Ward, op. cit., note 10 above, p. 224, commenting on the value of having doctors on hand to treat construction and mining accidents as they occurred, notes drily that "The popular notion of Egyptian taskmasters leaving sick and injured workmen to die under the boiling heat of the sun may have propaganda value for modern story-telling, but it has little basis in fact".

${ }^{30}$ Menu, op. cit., note 8 above, pp. 184-96.

${ }^{31}$ Ibid., pp. 140-67. 


\section{R. L. Miller}

number of workers in official project records. ${ }^{32} \mathrm{~A}$ relatively healthy group of workers would not only produce more, they would be easier to maintain at the numerical strength assigned to the task. ${ }^{33}$ Moreover, the officials and specialist workmen assigned to corvee projects would have also wished to take measures to ensure their own safe return home.

It is possible that some of the literary tradition of Egyptian medicine which has survived grew out of the medical and magical skills developed and maintained by skilled workers and the officials who supervised official projects, especially if both groups were literate, as was the case during the New Kingdom. ${ }^{34}$ While the occurrence of medical titles, and presumably skills, among the ranks of the officials, priests, and magicians working on government projects is well established, ${ }^{35}$ it is only recently that the extent of medical knowledge among workmen has become clear. The mixture of piety, magic, and careful observation which can be seen in the works of art produced by pharaonic craftsmen recurs in the medical texts, and it could be suggested that their creation, as well as their survival, owe much to the craftsmen who used them as well-tried magical and medical catalogues on which to pattern their own favourite charms and home remedies.

What medical problems would a physician or literate practitioner of medicine have encountered among his neighbours and clients? Many of the injuries, symptoms, and treatments referred to in the medical literature would have been common to all classes of Egyptian society. However, there is also some interesting evidence for a genre of tomb paintings and literature which was apparently familiar to skilled necropolis workmen depicting the health problems of less fortunate occupations.

\section{GENRE AND HEALTH: THE SATIRE ON TRADES}

A number of aspects of occupational health in ancient Egypt can be noted in art. The representation of occupational injury or disease could, on good evidence, be traced back to the third millennium BC. Old Kingdom reliefs at Saqqara depicting agricultural labourers, sailors, and fishermen, as well as porters carrying bundles of papyrus, are thought by Ghalioungui to depict ascites resulting from schistosomiasis and subsequent hernia ${ }^{36}$ the occupations pictured in these scenes would have involved frequent contact with water where the immature stages of the schistosome worm would be present. ${ }^{37}$ Ascites affected between 10-49 per cent of cases of schistosomiasis in a

\footnotetext{
32 Ibid., p. 124; Wb., III, 166-8, especially p. 168, 1: hsb, "Leute (von Arbeitern, Kriegern u. ä.)”, with the same hieroglyphic determinative depicting someone carrying a burden noted by Černý for smdt, op. cit., note 6 above, p. 185, cf. discussion of fay and note 59 below.

${ }^{33}$ As noted by Stuart, op. cit., note 19 above, p. 160, who estimated that a quarter of the work force he observed would have been adequate for the same task if well fed, supplied with tools, and supervised by experienced foremen.

34 See Pestman, note 75 below.

35 Jonckheere, op. cit., note 10 above.

${ }^{36}$ P. Ghalioungui, Magic and medical science in ancient Egypt, London, Hodder \& Stoughton, 1963, pp. 87-91, figs. 3-6, and especially the photographs of bargemen from Ptah Hetep's chapel, Saqqara, showing abdominal ascites and umbilical hernia (ibid., pls. 6-7) and the photograph of a fish carrier from Mehou's tomb, Saqqara, showing umbilical hernia and abdominal ascites (ibid., pl. 8a).

${ }^{37}$ R. Feachem, M. McGarry, and D. Mara (eds.), Water, wastes and health in hot climates, Chichester, Wiley, 1977, pp. 21, 27, 309.
} 


\section{Necropolis workmen in New Kingdom Egypt}

survey conducted in the upper reaches of the Nile in Uganda, ${ }^{38}$ and the frequency with which this form of pathology occurs in schistosomiasis cases supports Ghalioungui's diagnosis, which was based on his own considerable expertise in parasitology. The men carrying papyrus on the Saqqara relief are stooped under the weight of their load, ${ }^{39}$ and even without the swelling resulting from the accumulation of ascitic fluid in the abdomen, they would have been at risk of suffering from hernia, which was also an occupational hazard among porters carrying heavy loads in the eighteenth century. ${ }^{40}$

A Ramesside painting which may include an illustration of $\sin w$ at work (fig. 1) shows several accidents occurring among carpenters working on tomb furnishings: what may be a dislocated shoulder being treated, a mallet dropped on the foot, and someone who may be engaged in removing a chip of wood or metal from the eye. ${ }^{41}$

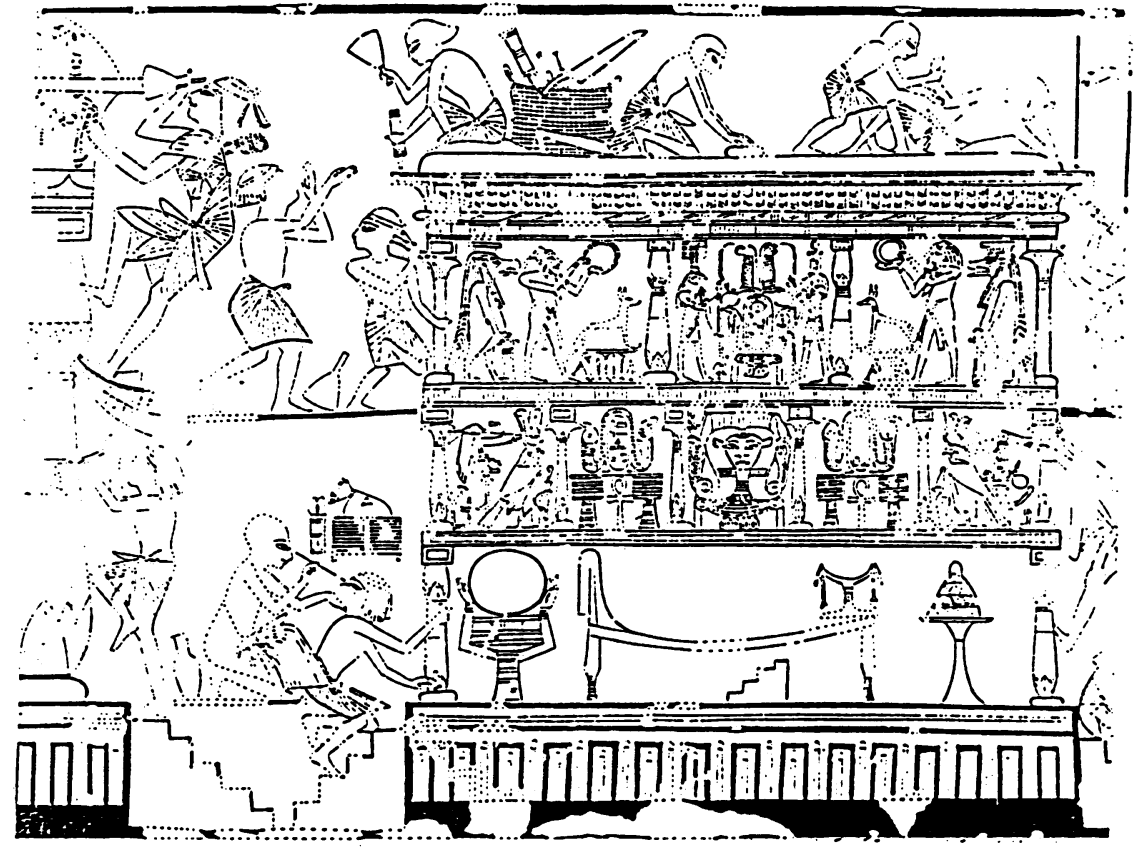

Figure 1. The Tomb of Ipy: accidents and eye treatment, possibly showing the removal of a foreign body from the eye. From Davies, op. cit., note 41 .

${ }^{38} \mathrm{~V}$. L. Ongom et al., 'The epidemiology and consequences of Schistosoma mansoni infection in West Nile, Uganda: II. Hospital investigation of a sample from the Panyagoro community', Trans. R. Soc. Trop. Med. Hyg., 1972, 66: 852-63.

39 Ghalioungui, op. cit., note 36 above, fig. 3.

${ }^{40}$ B. Ramazzini, Diseases of workers (W. C. Wright's translation of De morbis artificum, 2nd ed., 1713), University of Chicago Press, 1940, pp. 311-13.

${ }^{41}$ N. DeG. Davies, Two Ramesside tombs at Thebes, New York, Metropolitan Museum, 1927, pls. 31b, 37-8; on aspects of this scene relating to occupational medicine, see G. Lefebvre, op. cit., note 4 above, p. 73, and M. A. Dollfus, 'L'ophtalmologie dans l'ancienne Égypte', Arch. Ophtalmol., 1937, 1: 985-1001, see pp. 986-8. Davies (op. cit., pp. 69-70) considered that this scene depicted workers taking time off the job to relax. 


\section{R. L. Miller}

What is clearly an accident can be seen in the upper register on the left of the scene. I would read this as showing that something has entered the workman's eye, causing one hand to fly to his face as he gestures angrily towards the workman perched on the cornice of the funerary cult furniture above him, startling another workman who drops his mallet on the injured man's foot. The workman on the cornice was engaged in removing chips with a mallet and chisel, and a chip from the wooden bier or the mallet, or even a flake from the copper chisel, could have entered the injured man's eye. Such an injury would require emergency treatment, and the risks of surgery would be less than the risk of blindness resulting from an infection associated with microorganisms introduced with the foreign body, the eventual decay of the wood, or ulceration and corneal chalcosis occurring as the eye reacted to a fragment of copper. ${ }^{42}$

In this suggested reading of the scene on Ipy's tomb, the upper left hand register could be linked with the one below it, which Dollfus suggested represented the removal of a foreign body from a carpenter's eye. ${ }^{43} \mathrm{~A}$ patient is advised to look in a direction which allows the best view of the embedded foreign body, ${ }^{44}$ and the patient in the scene from Ipy's tomb kneels on the steps looking back over his shoulder allowing the light to reflect off his cornea and the speck of copper or wood in it, while the physician is able to look towards the dimmer light of the interior where he will be able to see better. The slightly flared end of the stick by the eye of the seated man, as well as the length of its shaft, are consistent with the conventions used to depict a transverse arrow, a makeshift scalpel which the guards of the necropolis workmen would have readily available. The straight edge of a transverse arrow would be well suited to making the

This interpretation may be correct for the workers extended on the roof of the bier, who could be enjoying a nap from which he is awakened by the shout of his master (whose arm is seen gesturing on the right). One of the other carpenters also lifts his arm in an attempt to wake him up. A mis-hit blow by a carpenter startled into action by the arrival of the overseer on the scene may also have started the sequence of events depicted on the left-hand side of the bier.

${ }^{42}$ S. Duke-Elder, System of ophthalmology, vol. 14, London, Kimpton, 1972, pp. 451-68.

43 Dollfus, op. cit., note 41 above, p. 987; idem, 'L'ophtalmologie dans l'ancienne Égypte', Bull. Soc. Franc. Égyptol., 1967, 49: 12-23, see pp. 14-15. Davies's suggestion (op. cit, note 41 above, p. 69) that this represents cosmetic being applied to the seated man's eyes is also a possible interpretation. Although excavated cosmetic sticks are generally much shorter, a long stick with a thickened end is used to apply lipstick in a depiction of a woman in an erotic Ramesside papyrus (Dynasty XX, 1196-1180 BC; W. H. Peck and J. G. Ross, Drawings from ancient Egypt, London, Thames \& Hudson, 1978, p. 94, fig. 21). However, it seems more likely that people would have applied their own eye make-up and would not need to brace themselves against a support while it was being applied. These objections do not apply if some form of medical treatment is involved, and it is significant that Davies does not assume that the scene is only cosmetic. As he describes the scene on Ipy's tomb, "the professional kohl-painter is treating the eyes of one of the carpenters ... who turns his head from his work to be attended to" (op. cit., p. 69). It is possible that the scraping of trachomatous eyelids with crushed abrasives is depicted here. Recipies for abrasive eye powders are known from the Ebers Papyrus (e.g. Papyrus Ebers 673: H. Grapow et al., op. cit., note 4 above, vol. 4(1), p. 26), and the daily scouring of eyelids with copper compounds to destroy diseased tissues was considered the only effective treatment of trachoma until the introduction of sulphonamides in 1938, according to S. Duke-Elder, op. cit., note 42 above, vol. 8, 1965, pp. 293-94. In Egypt a century ago, kohl is said to have been used in attempts to control eye infections rather than primarily as a cosmetic, according to J. B. Piot, 'Causerie ethnographique sur le fellah', Bull. Soc. Khéd. Géog. Caire, 1899, 5: 203-47, see p. 213.

${ }^{44}$ S. J. H. Miller, Parsons' Diseases of the eye, 17th ed., Edinburgh, Churchill Livingstone, 1984, p. 242. 
superficial incision in the cornea required to excise foreign objects. Such an operation is straightforward and recommended as suitable for training eye surgeons. ${ }^{45}$

Both Old and New Kingdom tomb paintings representing occupational accidents, disabilities, and deformations may come from a common visual tradition that could be related to the well-known literary genre represented in Middle and New Kingdom texts and known as "the satire on trades". ${ }^{46} \mathrm{~A}$ similar pictorial genre may be represented in art, with the discomforts and disfigurements associated with some occupations reproduced on tomb walls. ${ }^{47}$ Literate New Kingdom workers frequently used broken potsherds and split pieces of layered limestone as ostraca for recording a wide variety of school exercises, administrative texts, personal documents, and commercial and legal records. Numerous Ramesside ostraca with copies of the satire on trades survive, among them examples from Deir el Medina. ${ }^{48}$ The workmen who created and were buried in the Theban tombs could be expected to have recognized visual allusions to

\footnotetext{
45 M. J. Roper-Hall, Stallard's eye surgery, 6th ed., Bristol, Wright, 1980, p. 3. Papyrus Ebers 412 suggests a quantity of flaked stone $(d s)$ and terebinth resin for the treatment of another eye disorder, and a freshly flaked chip set into a lump of resin and hafted onto a reed would make a sterile surgical tool with a disposable cutting edge. The slight swelling on the end of the reed in the eye treatment scene could represent a lump with a flaked stone set into it. Lefebvre, op. cit., note 4 above, pp. 77-8, identifies this eye disorder, äjet or ādet, with pterygium, following B. Ebbell, Alt-ägyptische Bezeichnungen für Krankheiten und Symptome, Oslo, Skrift. Norsk. Vidensk. Akad., 1938, p. 6. Ajet occurs in the nasal corner of the eye (Grapow et al., op. cit. in note 4 above, vol. 7 (1), 1961, p. 74 n. 2; K. R. Weeks, 'The anatomical knowledge of the ancient Egyptians and the representation of the human figure in Egyptian art', Ph.D., Yale University, 1970, pp. 30-1), which is the usual location of pterygium, a winged-shaped ingrowth of conjunctiva encroaching on the cornea (P. D. Trevor-Roper and P. V. Curran, The eye and its disorders, 2nd ed., Oxford, Blackwell, 1984, p. 363). Pterygium is strongly associated with outdoor work in arid climates where the eye is exposed to solar untraviolet light, and has also been found to be strongly associated with occupational exposure to excess ultraviolet radiation among Japanese welders (D. J. Moran and F. C. Hollows, 'Pterygium and ultraviolet radiation: a positive correlation', Br. J. Ophthalmol., 1984, 68: 343-6; Ichiro Karai and Shun'ichi Horiguchi, 'Pterygium in welders', ibid., pp. 347-9). Pterygium can be treated by primitive surgery (e.g., A. Hrdlička, Physiological and medical observations among the Indians of Southwestern United States and Northern Mexico, Bureau of American Ethnology Bulletin 34, Washington, D.C., Smithsonian Institution, 1908, p. 237). Papyrus Ebers 412 specifies $d s \mathrm{~km}$, "dark flaked stone" for what is presumably the surgical treatment of pterygium. As $d s$ can refer to glass and obsidian as well as flint, could the arrow with a flake of blue glass hafted onto the end of a reed arrowshaft found in the tomb of Tutankhamūn (W. McLeod, Self bows and other archery tackle from the tomb of Tut'ankhamūn, Oxford, Griffith Institute, 1982, p. 59) perhaps be an example of the kind of tool also used in eye surgery in New Kingdom Egypt? How early was eye surgery in Egypt? A number of eye specialists are referred to in Old Kingdom sources (P. Ghalioungui, The physicians of pharaonic Egypt, Mainz, Von Zabern, 1983, p. 100). While the preparation of collyria would have been an important function of this class of physicians, pieces of stone and tools, which sometimes need surgical removal, frequently enter the eyes of quarryworkers and stone masons working without goggles. There may also have been an increased risk of pterygium occurring among corvee workers and specialist tomb craftsmen working on the quarrying and construction of limestone funerary monuments in the desert, to judge by the epidemiology of this condition in Egypt in the mid-twentieth century. An Egyptian ophthalmic surgeon practising in Akhmin district, Upper Egypt, which was "a district . . full of cases of pterygia", with an incidence of approximately 300 per 100,000, found the highest incidence of pterygia in desert villages, notably Issawiya village, where a third of the population was employed as stone cutters. Lower incidences of this pathological condition were found in the villages situated in the Nile Valley, and pterygia disappeared spontaneously in the case of one government official who left Akhmin to live in Cairo (S. Kamel, 'Pterygium. Its nature and a new line of treatment', Br. J. Ophthalmol., 1946, 30: 549-63, see pp. 558-9).

${ }^{46}$ W. Helck, Die Lehre des Dwä-Htij, 2 vols., Wiesbaden, Harrassowitz, 1970; M. Lichtheim, Ancient Egyptian literature, 3 vols., Berkeley, University of California Press, 1973-80, see vol. 1, pp. 184-92 and vol. 2, pp. 168-75.
}

47 Davies, op. cit., note 41 above, p. 53.

${ }^{48}$ References in Lichtheim, op. cit., note 46 above, vol. 1, p. 185. 


\section{R. L. Miller}

this genre in the scenes of daily life depicted on the walls of tombs. As the purpose of tomb scenes was to reproduce the environment in which the deceased tomb-owner could continue his existence, the picturing of disfigured workmen added verisimilitude, and may represent a closely observed depiction of actual working conditions which comes close to epidemiology, as much as a satirical genre which is not always clearly comic.

The similarity between these scenes and the texts of the papyrus rolls may have been intentional, especially if the paintings were produced by workmen who were themselves literate in some instances. ${ }^{49}$ The parallel between verbal and visual texts may have been another example of a correspondence between words and images similar to the convention used for painting religious texts in tombs where "the walls were, in a magical sense, papered with enlarged open rolls of papyrus bearing the required texts". 50 One of the closest correspondences between a literary text and a scene in a tomb painting occurs in the tomb of the sculptor Ipy, where mishaps afflicting carpenters and wood carvers have already been noted. In his publication of this tomb in 1927, Davies already noted the contrast between the happy existence of the aristocracy and the hard slog of their gardeners depicted on the tomb walls. ${ }^{51}$ The relationship between the text of the satire on trades and the illustration of the gardener on the walls of Ipy's tomb is certainly close and merits a closer examination from an epidemiological, as well as an artistic perspective.

The hump-backed gardener operating a shaduf in the tomb of Ipy (fig. 2) ${ }^{52}$ may be shown with a bursa or scoliosis which could perhaps be related to a secondary infection aggravating the repeated strain of operating the counterweighted water-lifting sweep to irrigate the

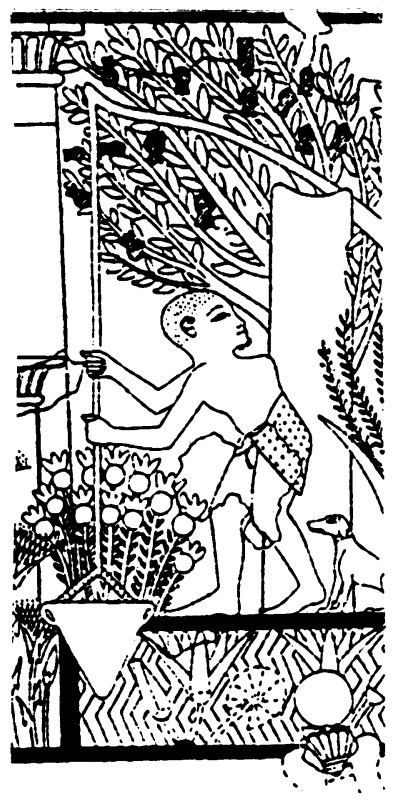

Figure 2. The Tomb of Ipy: hump-backed gardener operating a shaduf. From Davies, op. cit., note 41 above.

${ }^{49}$ See Pestman, op. cit., note 75 below, p. 161.

${ }^{50}$ T. G. H. James, Pharaoh's people, London, Bodley Head, 1984, p. 158.

${ }^{51}$ Davies, op. cit., note 41 above, p. 53 . The relation between the literary genre and its artistic parallels is complex and can only be briefly noted here. This tomb depicts many elements of occupational life in Ramesside times, alongside conventional, archaic scenes (Valbelle, op. cit., note 3 above, pp. 172-3, 298). In addition to its function of recording and immortalizing the skills of Ipy and his sons (ibid., p. 298), the tomb decoration may also rework and adapt conventions related to the satirical genre concerning the occupations, to which it and another example from Deir el Medina refer (ibid., p. $173 \mathrm{n}$. 2).

52 For the illustration of a shaduf worked by a hunchback, see Davies, op. cit., note 41 above, pls. 28-9. This has also been taken as an example of tubercular pathology, Pott's Disease (D. Morse, 'Tuberculosis', in D. Brothwell and A. T. Sandison (eds.), Diseases in antiquity, Springfield, Charles C. Thomas, 1967, pp. 249-71, see p. 263 and fig. 5). The study of hunchbacks in art and osteoarthritis in skeletons led Morse to conclude that tuberculosis was absent from pre-Columbian American populations and present in ancient Egypt, in both cases on much the same kind of pathological evidence (D. Morse, 'Prehistoric tuberculosis in America', Am. Rev. resp. Dis., 1961, 83: 489-504; D. Morse, D. R. Brothwell, and P. J. Ucko, 'Tuberculosis in ancient Egypt', ibid., 1964, 90: 524-41). The mobilization of large numbers of people to act as bearers and 


\section{Necropolis workmen in New Kingdom Egypt}

garden. ${ }^{53}$ London market porters used to be known for having occupational bursa variously called Covent Garden hummy, humpers' lump, or Billingsgate hump. ${ }^{54} \mathrm{The}$ Ramesside gardener's hump may also, perhaps, have developed from having to carry loads of vegetables and garden produce on his back, like the gardener referred to in a Middle Kingdom satire who "carries a yoke, his shoulders are bent as with age; there's a swelling on his neck and it festers". ${ }^{55}$ In Ramesside documents, gardeners carrying vegetables are mentioned along with water carriers and fishermen as porters working to supply the workmen of the Theban necropolis. ${ }^{56}$

These porters were needed to carry provisions for the workmen and their families, and at one time 16 men were working as porters for the 240-300 inhabitants of the village, as well as for the workmen during the shifts they worked on the necropolis site. ${ }^{57}$ On one occasion, when the crew working on the tombs in the Valley of the Kings was bigger than was needed, some of the workmen were sent outside the village to become $s m d t$, and reduced to the status of porters. ${ }^{58}$ Instead of having things fetched and carried for them, the former royal tomb workmen would have had to carry commodities and other burdens for

Figure 3.

Hieroglyphic sign, fây, "carrying". the state, performing the corvee labour enforced on most of the population of ancient Egypt except for those, like the necropolis workmen and the officials above them, who were specifically exempted

porters may be a factor common to both areas, although tuberculosis may well have played a significant part in the genesis of the pathology in both areas. Although acid fast bacteria have been demonstrated in mummy tissue, direct demonstration of mycobacterial antigen would be useful. Using ELISA to determine the presence or absence of mycobacterial antigen-antibody complexes in mummy tissue could perhaps be successful using techniques already applied in retrospectively diagnosing smallpox (G. Fornaciari and A. Marchetti, 'Intact smallpox virus particles in an Italian mummy of sixteenth century', Lancet, 1986, ii: 625; ibidem, 'Italian smallpox of the sixteenth century', ibid., pp. 1469-70) as well as schistosomiasis (Deelder et al., op. cit., note 5 above).

${ }^{53}$ A study of miners opening a new seam which had to be worked kneeling, using a workforce not accustomed to working in this posture, found that people who were susceptible to staphylococcal infection and were already heavy carriers of pathogenic staphylococci before beginning work were more likely to suffer acutely swollen and painful bursae (J. B. Atkins and J. Marks, 'The role of staphylococcal infection in beat disorders', Br. J. ind. Med., 1952, 9:296-302). Genetic factors may play a role as well. Reactive arthritis and fused backbone joints are more common among people with HLA B27 antigen when they contract a variety of relatively commonplace gut pathogens than among the majority of population with other HLA types (reviewed by J. Dausset, 'Clinical implications', in J. Dausset and A. Svejgaard (eds.), HLA and disease, Copenhagen, Munksgaard, 1977, pp. 296-310). A Hungarian study even found that in cases of chronic brucellosis HLA B27 was significantly associated $(p<0.01)$ with the occurrence of exudative arthritis, severe back pain and radiological evidence of sacroiliitis or osteochondritis in dorsal vertebrae (L. Hodinka et al., 'HLA-B27-associated spondylarthritis in chronic brucellosis', Lancet, 1978, i: 499).

${ }^{54}$ D. Hunter, The diseases of occupations, 6th ed., London, Hodder \& Stoughton, 1978, pp. 780-1.

${ }^{55}$ Lichtheim, op. cit., note 46 above, vol. 1, p. 187; Helck, op. cit., note 46 above, vol. 1, pp. 71-5. Papyrus Ebers 295 gives a treatment specifically for someone with a neck bursa accompanied by a stiff neck and inability to look at his belly. The physician is to say, "It is a neck bursa" and follow the diagnosis with topical applications of a salve until it gets better (Grapow et al., op. cit., note 4 above, vol. 4 (1), pp. 68-9).

56 Černý, op. cit., note 6 above, pp. 185-6.

57 Ibid.

${ }^{58}$ According to Ostracon Berlin 12654, vol. 1-3, "So says the vizier: Leave these sixty men here in the gang, any you choose, and send the surplus outside. Give the order, that they should become ... serfs [smdt] who carry for you" (translated by Černý, ibid., p. 185). Smdt were "servants with a status close to slavery" (Valbelle, op. cit., note 3 above, p. 130), defined in texts from Deir el Medina as "those who carry" for the crew of skilled workmen resident in the village (ibid., p. 131, citing three examples including O. Berlin 12654); cf. $W b .$, IV $, 147,2-7$. 


\section{R. L. Miller}

from this form of tax, which was graphically represented by the hieroglyphic sign $f a \bar{y}$, "carrying" (fig. 3). 59

It may be possible to identify the kind of pathology which hard labour as a porter could produce. In his survey of occupational disease, Hunter illustrated a London fish porter with Billingsgate Hump, a bursa over the lower cervical spine at the top of the backbone, just below the neck, ${ }^{60}$ very similar to the hump on the gardener in the tomb painting. ${ }^{61}$ Hunter also reproduced ${ }^{62}$ an illustration of severe scoliosis caused by carrying heavy loads on the shoulder originally published in 1886 by the surgeon W. Arbuthnot Lane, who conducted post-mortem studies of porters, draymen, and other workers subjected to abnormal spinal loading who died relatively young, before senile changes had obscured work-related osteoarthritis (fig. 4). ${ }^{63}$ In what would be one of the earliest attempts at palaeopathology, Lane apparently identified similar load-related pathology in ancient bone as well as in a mummy, ${ }^{64}$ although he does not illustrate these findings. ${ }^{65}$

The high incidence of calcified intervertebral discs in ancient Egyptian populations has been frequently noted. ${ }^{66}$ While the exact cause is unknown, and may also be related

59 Wb., 573, 9. 10; Černý, op cit., note 6 above, p. 185.

${ }^{60}$ Hunter, op. cit., note 54 above, fig. 275.

61 Tomb of Ipy, Davies, op. cit., note 41 above, p. 53, pls. 28-9.

${ }^{62}$ Hunter, op. cit., note 54 above, fig. 272.

${ }^{63} \mathrm{~W}$. A. Lane, 'Some points in the physiology and pathology of the changes produced by pressure in the bony skeleton of the trunk and shoulder girdle', Guy's Hosp. Rep., 1886, 43: 321-434, see fig. 1.

64 Ibid., p. 323.

${ }^{65}$ Lane's detailed observations and careful description are still worth consulting. In his introduction, he noted, "by examining bones we can judge from their form and texture as to whether they have transmitted exaggerated weight or heavy loads, and if so, in what manner those loads have been supported on the trunk. In fact, in labourers, we can detect their previous career of labour. I need not point out the value of these facts from a medico-legal and also from an archaeological aspect" (ibid., p. 323, italics in the original). If Lane's notes or records on the 120 or so cases of load-carrying pathology he examined (ibid., p. 323) have survived a century, two wars, and destruction of written records after the introduction of computers, they would be invaluable. His pioneering work also has many valuable observations on biomechanics, although he may, perhaps, have underestimated the effect of tuberculosis on his sample (e.g., the case of the man employed as a barrel shive maker and firewood carrier who developed curvature of the spine after working bent over all day and died at 27 from "severe capillary bronchitis", ibid., p. 359). Lane also described the curvature of the spinal column produced by carrying loads in a harness pressing against the forehead (ibid., pp. 355-8, fig. 9), and it would be interesting to compare his observations with X-ray archives of hospitals in Turkey, Syria or Lebanon treating porters using this method of bearing a load. In the early twentieth century AD the hamal of Istanbul were typically hunchbacked according to E. Kazan, A life, London, Pan, 1988, p. 688. However, the bursae produced by connective tissue to protect the underlying bone would not necessarily be associated with vertebral pathology in all cases, and the appearance of a hump in soft tissue depicted in art or noted by observers in the working environment would not always show up in the skeleton. There are inevitably disjunctions between different categories of clinical and pathological evidence.

${ }^{66}$ See reviews by M. A. Ruffer, 'On osseous lesions in ancient Egyptians', Studies in the palaeopathology of Egypt, University of Chicago Press, 1921, pp. 93-126, and by I. Isherwood, H. Jarvis, and R. A. Fawcitt, 'Radiology of the Manchester Mummies', in David (ed.), op. cit., note 5 above, pp. 25-40, especially pp. 37-8. According to another radiographer, the diffuse increase in density of intervertebral discs noted in 12 out of $29 \mathrm{New}$ Kingdom skeletons examined, has no comparably common counterpart in the range of pathological effects seen in skeletons of the twentieth-century population most familiar to radiographers (W. M. Whitehouse, 'Radiologic findings in the Royal Mummies', in J. E. Harris and E. F. Wente (eds.), An $X$-ray atlas of the Royal Mummies, University of Chicago Press, 1980, pp. 286-327). Are all these mummies royal? In contrast to Tutankhamūn, who was found in his own tomb, there is no certainty about the identity of many of the cache of mummies discovered in the nineteenth century near Thebes, as labels could have been 


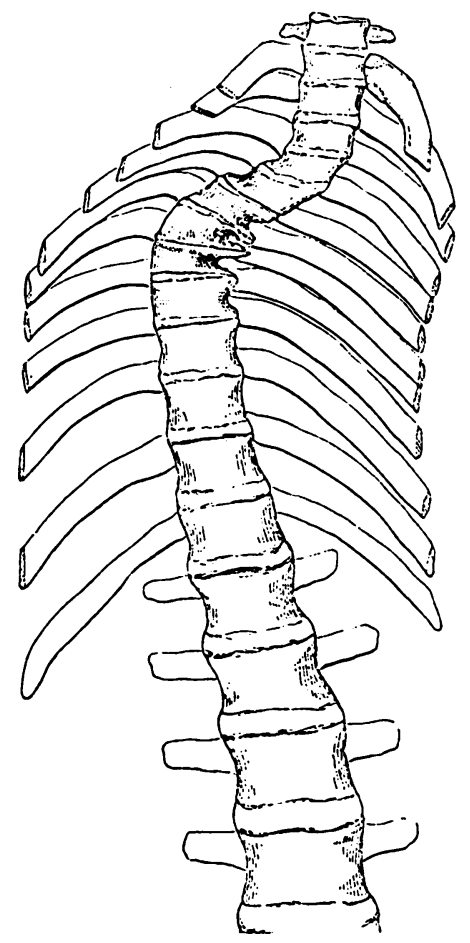

Figure 4. Scoliosis of thoracic spine in a porter accustomed to carry loads on his right shoulder. From Lane, op. cit., note 63, fig. 1.

to aspects of population biology and disease, could some of the incidence of this pathological condition be related to work as smdt porters and corvee labour? ${ }^{67}$ Thanks in part to advances in construction machinery, few modern populations have been subjected to the massive forced-labour mobilization which characterized pharaonic Egypt, but Lane's sample of porters may have been exposed to ranges of back loading similar to those experienced by ordinary Egyptians during corvee labour that required huge amounts of stone and earth to be moved on pharaonic building and tomb projects. Seasonal or intermittent mobilization as corvee labour for carrying supplies and commodities, building materials, and earth from canal cleaning ${ }^{68}$ might have led to vertebral involvement less severe than year-round labour as a porter. As the

accidentally misplaced and identifications confused in antiquity. Embalmers may also have been less careful about their work than was suspected until recently. For example, ancient labels on canopic jars do not necessarily bear any relation to the contents and lung tissue has been preserved in jars labelled as liver (Walker et al., op. cit., note 5 above). However it would be unjustified to be too sceptical about the status of this cache. Although there is doubt about the identification of many of the mummies in the royal and other caches, it is probable that most of the bodies were people of high status in life. Certainly some disease processes, in addition to artifacts of embalming procedures, may have contributed to the vertebral feature of ancient Egyptians noted on X-rays and in autopsy.

${ }^{67}$ For corvee labour see Kemp, op. cit., note 7 above, pp. 82-9, and Menu, op. cit., note 8 above, pp. $114-15,123-27$.

${ }^{68}$ Ibid., pp. 114-15, 123. 
eighteenth-century pioneer in occupational medicine, Ramazzini, noted, "All porters become in time round-shouldered, because the dorsal vertebrae are constantly bent forward and become set in that position. For although they know none of the laws of mechanics, nature has taught them that it is easier to carry weights on the shoulders with the chest hollowed, than with the body erect". ${ }^{69}$

The occupational deformation of gardeners acting as porters is not the only form of occupational pathology referred to in literary sources. The texts of satires mention the unpleasant fevers, dangers, discomforts, and injuries endemic to a number of non-scribal occupations: jewellers and wall builders have cramped arms and aching joints, weavers spend their time in a darkened workshop squatting with their knees against their belly, tenant farmers and messengers are worn out with long journeys, ${ }^{70}$ foot-soldiers are injured in training and reduced to the condition of invalids during campaigns. $^{71}$ Only the scribe is able to relax and enjoy good health as well as ideal working conditions. ${ }^{72}$

${ }^{69}$ Ramazzini, op. cit., note 40 above, p. 311.

70 W. Helck, op. cit., note 46 above; M. Lichtheim, op. cit., note 46 above, vol. 1, pp. 184-92 and vol. 2 , pp. 168-75. It is interesting to note that, apart from the soldier (see following note) actual pathological changes are mainly associated with the gardener/porter, and that discomfort and fatigue are the main problems for other occupations. Despite the weaver's uncomfortably cramped position and fatigue, no overt pathology is recorded for this occupation, results confirmed by Ramazzini (op. cit., note 40 above, pp. 431-5) and a recent study of the skeletons of relatively well-off weavers of Spitalfields parish, London, who were able to afford the security of a crypt burial (cf. T. Waldron, Am. J. phys. Anth., 1989, 78: 319). The position in which the Egyptian weaver is described as working, with the knees against the chest, is also illustrated in Middle Kingdom tomb paintings of women weaving (H. Hodges, Technology in the ancient world, Harmondsworth, Penguin, 1970, fig. 104). This pattern of activity could have resulted in some knee osteoarthritis, however. While skilled craftsmen like weavers or carpenters are usually depicted sitting on small stools while working (James, op. cit., note 50 above, figs. 22 and 20), this may be an idealized picture, although details in the satire on trades would also have been exaggerated for comic effect. Squatting positions which would have had an effect on knee joints if maintained for many hours at a stretch were, however, pictured being used by a carpenter planing a column of wood (ibid., fig. 20). There may be some palaeopathological evidence for the squatting posture. Unusually early osteoarthritic changes to the knee joints of one adult male aged about 20 were noted in Manchester Mummy 1768, a 1 st/2nd century AD Roman period burial from the Fayoum, who suffered from osteoarthritis in both knees, accompanied by sclerosis of tibial plateaux and cartilage opacification (Isherwood et al., op. cit., note 66 above, p. 32, fig. 25). While neither congenital nor infectious factors can be ruled out, it is possible that this youthful knee problem could perhaps be partly related to occupational factors such as those depicted on tomb paintings and described in the satire on trades. The osteoarthritis shown by the radiograph of Mummy 1768 is similar to the X-ray of painful knee osteoarthritis observed recently in an Indian clinic, where a high frequency of knee pathology was ascribed to the habit of adopting a squatting position (R. N. Villar, V. K. Solomon, and J. Rangam, 'Knee surgery and the Indian knee', Tropical Doctor, Jan. 1989, 19: 21-4). The similarity in the knee pathology revealed by X-rays on 1768 and the Indian cases could conceivably be related to a pattern of joint stress shared by both.

${ }^{71}$ According to one satire on an infantryman's life, "he is taken away in childhood and put in a camp. A sickening blow is directed against his stomach, a splitting blow against his eye and a stunning blow against his eye-brow... Then comes the march to Palestine, the battle in the desert ... He has to drink brackish water and stops marching only to be on guard. When he reaches the enemy, he is like a bird in a trap, without any strength in his body. When he returns to Egypt he is like worm-eaten wood. He becomes ill, and has to lie down and is brought back on a donkey": transl. J. Yoyotte, article 'Army', in G. Posener (ed.), A dictionary of Egyptian civilization, London, Methuen, 1962, p. 16. See also Lichtheim, op. cit., note 46 above, vol. 2, p. 172. Yoyotte comments, "There is every reason to believe that these cruel hardships were not exaggerated" (loc. cit.). A review of the medical aspects of ancient warfare is provided by P. B. Adamson, "Medical complications associated with security and control of prisoners of war in the ancient Near East', Med. Hist., 1990, 34: 311-19.

${ }_{72}$ Lichtheim, op. cit., note 46 above, vol. 2, pp. 165-78; scribal work and status are discussed by James, op. cit., note 50 above, pp. 132-80. 


\section{Necropolis workmen in New Kingdom Egypt}

Part of the scribes' complacency may have derived from their familiarity with the spells and prescriptions used to treat disease and avert ill-fortune. Egyptian medicine was always mixed with magical incantations, ${ }^{73}$ and in the Edwin Smith Papyrus, a copy of a text on surgery and the treatment of wounds and injuries was left incomplete, while incantations to treat illness were copied out, much to the disgust of the twentiethcentury editor and translator. ${ }^{74}$ However, with the recent discovery that ordinary workmen at Deir el Medina were literate,$^{75}$ and possessed their own copies of texts including medical prescriptions, haemorrhoid cures, books of dream interpretation, prophylactic spells, and incantations against scorpion stings, ${ }^{76}$ it is possible to wonder whether or not the New Kingdom medical literature we possess represents in part the interests of literate households without specialist medical training, collecting books of home remedies. ${ }^{77}$

\section{PHYSICIANS, LITERACY AND POPULAR MEDICAL TRADITIONS AT DEIR EL MEDINA}

Although physicians are mentioned in a number of documents from Deir el Medina, we know few of the physicians there by name. An ushabti from Deir el Medina refers to a wr sinw $m$ st $m \bar{a}$ 't, "Chief physician in the Place of Truth" (i.e., chief physician of the Necropolis) ${ }^{78}$ While the person named on this ushabti, Pwr, is not yet attested in the ostraca from Deir el Medina, ${ }^{79}$ some indication of the status of ordinary physicians

\footnotetext{
${ }^{73}$ The coincidence of medical and magical skills is already implied in both of the graffiti from Hatnub already referred to, note 15 above. See also Ghalioungui, op. cit., note 36 above; G. Lefebvre, op. cit., note 4 above, pp. 7-16; S. Sauneron, article 'Magic' in Posener (ed.), op. cit., note 71 above, pp. 155-7; an exhaustive review of the literature is found in W. Gutekunst, article 'Zauber', $L \ddot{A}$ 6, cols. 1320-55. As Grapow noted, there was no clear distinction between medical and magical treatment, and the binding of fresh meat on crocodile and pig bites recommended in the medical papyri was apparently a form of sympathetic magic (op. cit., note 4 above, vol. 3, pp. 128-9 and vol. 4, p. 211).

${ }^{74}$ Breasted, op. cit., note 4 above, pp. 15-16, 19-20. Breasted's assumption that the stages of textual history correspond to the interests of successive owners who were a surgeon, a general practitioner, and a quack (ibid., pp. 19-20) involve assumptions about the limits of literacy which can no longer be accepted as valid (see following note).

${ }^{75}$ P. W. Pestman, 'Who were the owners, in the "community of workmen", of the Chester Beatty Papyri', in R. J. Demarée and J. J. Janssen (eds.), Gleanings from Deir el-Medina, Leiden, Nederlands Instituut voor het Nabije Oosten, 1982, pp. 155-72. 'Imn-nkhtw, the owner of the Chester Beatty Papyri, "is attested to as a simple workman under Ramesses IV and V, but he was able to write, and proudly called himself $\breve{s s " ~(i b i d ., ~} \mathrm{p}$. 161). As Pestman indicates, šs can now be seen to designate anyone capable of writing, although it often indicates an official holding the position of scribe (ibid., p. 171 n. 36).

76 Ibid., p. 165; for a translation of the Chester Beatty medical papyrus, largely concerned with diseases and treatments of the anus, see Jonckheere, op. cit., note 4 above.

${ }^{77}$ Pestman, op. cit., note 75 above. If the Harris Papyrus, the Edwin Smith surgical papyrus, and the Ebers Papyrus were found together in a tomb near Deir el Medina in the mid-nineteenth century, as Breasted suggested may have been possible (op. cit., note 4 above, p. 25), the eclectic interests of these medical papyri would be consistent with what is now known of the tastes of a literate worker's household in Deir el Medina revealed by Pestman (op. cit., note 75 above).

78 Jonckheere, op. cit., note 10 above, p. 38, no. 27, Vatican ushabti 1383; Valbelle, op. cit., note 3 above, p. $128 \mathrm{n}$. 1. Ushabtis were mummy-shaped figurines placed in a tomb to enable the deceased to avoid corvee labour in the afterlife. If the owner was posthumously summoned to cultivate or irrigate fields, his ushabtis were empowered to do the required work on his behalf (H. D. Schneider, Shabtis, 3 vols., Leiden, National Museum of Antiquities, 1977, see vol. 1, pp. 2, 4, 16, 82-152). Ushabtis carried the tools required for corvee labour: a hoe, pick, basket, yoke with water pots, and sometimes a brick mould (Eyre, op. cit., note 19 above, pp. 207-8).

${ }^{79}$ Valbelle, op. cit., note 3 above, p. 128, n. 1.
} 


\section{R. L. Miller}

attached to the crews of tomb workmen can be gathered from the ostraca so far published from the site. These give little indication of the range of skills sinw may have possessed or the operations they could have performed, but these skills can perhaps be reconstructed from other sources by a combination of textual, archaeological, and epidemiological approaches.

The physician for the crew of necropolis workmen early in the Ramesside period was one of the workmen themselves, and there are indications that he may have been relatively poorly paid. Whereas the normal salary for a workman was a monthly ration of 4 khar of wheat for bread plus $1 \frac{1}{2}$ khar of barley for home brewing, the sinw received only 1 khar of wheat and $\frac{1}{4}$ khar of barley. ${ }^{80}$ While it could be argued that the wages given to the physicians supplemented his salary as an ordinary workman, ${ }^{81}$ this is not stated in the text and the most recent study of the workmen concludes that these low wages, equal to those of a porter, were all that he got. ${ }^{82}$

One and a quarter khar of grain per month may have been close to the Ramesside equivalent of a minimum wage. If a khar contained 76.48 litres of grain, ${ }^{83}$ with wheat weighing $785 \mathrm{~g} /$ litre and barley $705 \mathrm{~g} /$ litre, ${ }^{84}$ and with energy values of $354 \mathrm{Kcal} / 100 \mathrm{~g}$ and $360 \mathrm{Kcal} / 100 \mathrm{~g}$ respectively for Middle Eastern wheat and barley, ${ }^{85}$ some 261,057 kilocalories of energy would have been available from the physician's ration. This would be enough to support a household of four people for 30 days with about 2,175 Kcal per person per day, close to the 1917 Egyptian ration of 2,200 calories a day for feeding prisoners with no work. ${ }^{86}$

Were sinw paid by results? Pehripije, the physician on the team of necropolis workmen in the year 40 of Ramesses II, is recorded as being absent from tomb work on

${ }^{80}$ Ostracon Cairo 25608, mid-Twentieth Dynasty, cited by Janssen, op. cit., note 6 above, p. 460 .

81 Ibid., p. 460.

82 Valbelle, op. cit., note 3 above, p. 127. Medical skills were not always highly rewarded even in mid-twentieth-century Egypt, as reflected in Naguib Mahfouz' novel Midaq Alley, where Dr Boushy, a dentist in a slum neighbourhood, is among the poorest of the alley's inhabitants, robbing a grave to get gold for his dental work (Midaq Alley, London, Heinemann, 1975, pp. 193-8).

${ }^{83}$ Using the figure of 4.78 litres per hekat (1/16 khar) supplied by K. Baer, 'The low price of land in ancient Egypt', J. Am. Res. Cen. Egyp., 1962, 1: 25-45, esp. p. 42. Janssen, op. cit., note 6 above, p. 109 gives a value of 76.88 litres/khar, which increases the amount of the following estimate by only $0.5 \%$.

${ }_{84}$ B. J. Kemp, 'Large Middle Kingdom granary buildings (and the archaeology of administration)', Zeit. ägyp. Spr. Alt., 1986, 113: 120-36, esp. p. 132.

85 Pellet and Shadarevian, op. cit., note 26 above, section 1, nos. 7 and 1 . Nutritional values in this handbook, compiled by nutritionists from their own tests and reliable assays by colleagues elsewhere in the Middle East, should be used. Correcting Kemp's figures with the values for wheat and barley published by Pellet and Shadarevian would mean the minimum Middle Kingdom bread ration for ten days of 1 hekat (4.78 1.) wheat and $2 / 3$ hekat barley weighing respectively $3.75 \mathrm{~kg}$ and $2.25 \mathrm{~kg}$ could have yielded $\mathrm{i}, 867$ calories/day, just above the prison subsistence ration recommended in Egyptian prisons in 1917 (see following note). 1,800 calories is also the temporary maintenance ration recommended for a period of only a few months by Simmonds et al., op. cit., note 27 above, p. 109. As corvee labour and military expeditions were both installed in temporary hnrt (Quirke, op. cit., note 18 above) enclosures, this ration would be adequate for the few months required for these undertakings as well.

${ }^{86} \mathrm{~A}$ report on prison diet in Egypt published in 1917 is referred to by Kemp, op. cit., note 84 above, p. 132. This report suggested daily rations of 1,800 calories for subsistence, 2,200 for prisoners with no work, 2,800 for light labour and 3,200 for hard labour. The tomb workers may have made good use of their extra ration. In the 1940s German coal miners who were receiving 2,800 calories/day and producing 7 tons/day per man increased their output to 9.6 tons/day when fed an extra 400 calories/day (Spurr, op. cit., note 28 above, p. 10). 


\section{Necropolis workmen in New Kingdom Egypt}

34 out of the 70 working days recorded. ${ }^{87}$ The lower salary he received could be commensurate with the fact that he worked with the tomb crew less often. His days away from the tomb were sometimes spent with the workers when they were off sick, although the illnesses are not specified. ${ }^{88}$ The physician was sometimes busy preparing prescriptions. On one occasion, the records show, Pehripije was with Khons, who had the day off work because of illness, and the physician was "making a medicine". 89 Another time, Pehripije had to spend at least 14 days away from work at the tomb to make a medicine required by the wife of the project's scribe, time perhaps required by the exoticism of the ingredients known to have been required by some medical prescriptions. ${ }^{90}$

Successful physicians would not have been totally dependent on their official salary. Considerable sums could be paid by the necropolis workmen for private medical treatment, as shown by the 22 deben (equivalent to the value of $2 \mathrm{~kg}$ of copper) which one workman, Usihè, paid for medical treatment to an unnamed doctor. ${ }^{91}$ As the monthly salary of a workman was $5 \frac{1}{2}$ khar of grain, valued at 11 deben of copper or its equivalent in other commodities, Usihè was willing to spend a relatively large sum, equivalent to two months' salary, on the services of a physician. ${ }^{92}$

However, were the physicians always responsible for the medical treatment the workmen received? While physicians were certainly practising locally and were employed among the tomb workmen, we have to be careful not to assume that medical knowledge was restricted to them. Privately-owned texts included medical papyri among the works carefully preserved, inherited, and collected ${ }^{93}$ As some of the craftsmen were literate, with differing tastes reflected in the collections of papyri they acquired, ${ }^{94}$ hieratic medical ostraca and spells could have been copied out by a number of workmen, and not necessarily by one of the professional $\sin w .{ }^{95}$ Any literate $̌ s$ could have written out the ostracon with a prescription for cough syrup found at Deir el Medina, ${ }^{96}$ or the magical spell to cure a cold which was wrapped in linen and tied around the throat of another workman in the village. ${ }^{97}$

As successful treatment could be well rewarded, ${ }^{98}$ the use of treatments which had been successful in the past, and the knowledge of how to treat or how not to treat illness could have been an additional source of income for workmen engaging in medicine as a sideline, like the building work, coffin decoration, and making of tomb furniture which some necropolis workmen undertook during free time and days off. ${ }^{99}$ In other cases,

${ }^{87}$ Janssen, op. cit., note 2 above, pp. 151-2.

${ }^{88}$ Ibid., p. 137.

89 Ibid.

90 Ibid.

${ }^{91}$ Papyrus Turin 1880, vs. 5, 2 ff., cited by Janssen, op. cit., note 6 above, p. 534 .

92 Ibid.

93 Pestman, op. cit., note 75 above.

94 Ibid.

${ }^{95}$ As assumed by Valbelle, op. cit., note 3 above, p. 285.

96 Ostracon Cairo 1037, published in F. Jonckheere, 'Prescriptions médicales sur ostraca hiératiques', Chron. Égyp., 1954, 29: 46-41, see pp. 49-50.

${ }^{97}$ S. Sauneron, 'Le rhume d'Anynakhte', Kêmi, 1970, 20: 7-18.

98 Janssen, op. cit., note 6 above, p. 534.

${ }^{99}$ Janssen, op. cit., note 2 above, pp. 144-5. 


\section{R. L. Miller}

medical prescriptions and magic spells could have been written out by someone for friends or family members, without either salaried or freelance medical practitioners being involved. This does not mean that such prescriptions and spells would not also have been written out and prepared by bona fide physicans. Nevertheless, with literacy and the ownership of texts, including medical texts, more widespread in ancient Egypt than has been recognized until recently, the existence of a popular, literate medical tradition should also be noted.

The point about literacy is worth making because religion is one of the main concerns of the texts in which the ancient Egyptians' medical tradition is preserved, insofar as they describe how to invoke the protection of, and pacify, many of the divinities whose images the necropolis workmen spent much of their lives carefully reproducing for the benefit of the current monarch. Magic and religion were essential parts of the medical tradition. The Ebers Papyrus begins with verbal formulae with which to initiate medical treatment, described by the author as "words to say when medication is applied to any sick part of a person's body". ${ }^{100}$ These words helped to ensure a successful course of treatment, and the formula itself is described as an "efficacious remedy, an incalculable number of times". ${ }^{101}$ Anyone able to repeat this formula could benefit from it, and any literate owner of the Ebers papyrus, who did not have to be a physician, could have used it.

Another example of the uses of literacy in the formulation of home cures can be seen in the treatment of scorpion bites among the villagers at Deir el Medina. Scorpion bites were common, ${ }^{102}$ and the sleeplessness and nausea that would have resulted in the loss of a day's work could perhaps have been soothed by the incantations of the formula to cure scorpion bites found in one of the texts owned by workmen at Deir el Medina. ${ }^{103}$ Scorpions would have been common on the edge of the desert, thriving in debris left around households in the village, as well as under stones and piles of earth and rubble from excavations in the necropolis. ${ }^{104}$ In desert communities in neighbouring areas of the Sahara, scorpion stings can now occur at the rate of 9 per 1000 population, although less than one per cent of these result in deaths, mostly among children under two. ${ }^{105}$ Local pain and fright are the most common results of scorpion stings, especially among adults, as the severity of clinical features usually depends on the amount of venom injected relative to the weight of the victim. ${ }^{106}$ Ancient Egyptians wishing to avoid scorpions or protect their household against them could have gone to a professional scorpion magician, who could provide them with protective amulets and spells. ${ }^{107}$ Again, the literacy of workmen with access to copies of such spells could have had an impact on the formulation and reinforcing of tradition.

${ }^{100}$ Lefebvre, op. cit., note 4 above, pp. 10-11.

101 Ibid., p. 11.

102 Janssen, op. cit., note 2 above, pp. 136-7.

103 Papyrus Chester Beatty VII A, cited by Valbelle, op. cit., note 3 above, p. 286 n. 5.

104 M. T. James and R. F. Harwood, Herm's medical entomology, 6th ed., London, Macmillan, 1969,

p. 114; R. Miller, 'Health care on field projects', J. Field Archaeol., 1984, 11: p. 438 n. 4.

105 P. E. C. Manson-Bahr and F. I. C. Apted, Manson's Tropical diseases, 18th ed., London, Baillière Tindall, 1982, p. 563-4.

106 Ibid., p. 564.

107 Valbelle, op. cit., note 3 above, pp. 285-6. 


\section{Necropolis workmen in New Kingdom Egypt}

Literate necropolis workmen could also combine the skills for which they were employed with their literacy to treat eye disease. When eye trouble affected necropolis workmen they could take time off work and they may have received house calls from the project's doctor, although this is not certain. ${ }^{108}$ They would also have taken other measures which were integral parts of the same medical tradition even though we might consider them religious or magical, such as erecting the eye steles found at Deir el Medina, which typically have pictures of ears to ensure a hearing from the different gods, who are invoked with a standard formula. ${ }^{109}$ As the eye trouble had been caused offending a divinity, as the stele texts frequently state, ${ }^{110}$ it was necessary to devote time and resources to placating the aggrieved god and invoking the support of other gods. ${ }^{11}$ These steles document a medical problem, eye trouble, and the use of the necropolis workmen's specialized skills in stone working, representational arts, and literacy to make enduring versions of the healing spells used to treat the eye.

What kind of eye trouble the workmen suffered from cannot be determined, although it is possible to suggest a range of potential disorders. Egypt was traditionally well known for a high incidence of infectious eye disease, ${ }^{112}$ and different seasonal prevalences in eye ailments recorded in pharaonic Egypt may perhaps correspond to seasonal peaks in trachoma and communicable ophthalmia recorded in the 1940s. ${ }^{113}$ However, in an area where trachoma is endemic, children are most likely to suffer severe cases, and fewer adults would be expected to experience active infections. ${ }^{114}$ Nevertheless, cases of trachoma or ophthalmia may have been responsible for the loss of some days off work among the necropolis workmen. Xerophthalmia can also be a problem following severe cases of diarrhoea or malnutrition, ${ }^{115}$ but the workmen were

\footnotetext{
108 Janssen, op. cit., note 2 above, pp. 136-7.

109 Valbelle, op. cit., note 3 above, p. 331; for publications of some of these steles in collections in London,
} Turin, and Bordeaux, see B. Gunn, 'The religion of the poor in ancient Egypt', J. Egyp. Archaeol., 1916, 3: 81-94 (British Museum stele nos. 276, 374, 589; as more has become known about the necropolis workmen it has become clear that they were not poor); M. Tosi and A. Roccati, Stele e altre epigrafi di Deir el Medina, Turin, Pozzo, 1972, stele nos. 50046, 50050-50052, pp. 80-1, 85-8, 90-1, 230 and photos on pp. 280, 282-3; J. J. Clère, 'Un monument de la religion populaire', Rev. d'Égyp., 1975, 27: 70-7, Bordeaux stele; an excellent review of blindness at Deir el Medina is found in $\mathrm{H}$. Brunner, art. 'Blindheit', $L \ddot{A} 1$, cols. 828-33.

110 Ibid.

111 Ibid.; Valbelle, op. cit., note 3 above, pp. 286, 310, 331.

112 Reviewed by S. Duke-Elder, op. cit., note 42 above, VIII, pp. 260-1.

113 A. Feigenbaum, 'Archaeological evidence of the occurrence of regular seasonal ophthalmias in ancient Egypt', Janus, 1957, 46: 165-72. In Cairo, seasonal epidemics of bacterial conjunctivitis typically occurred in May-June and October, followed six weeks later by high incidence of trachoma in August and December (R. P. Wilson, 'Trachoma, a selection of personal observations and experiences', Ann. Rep. Giza Mem. ophthalm. Lab., 1944, 14: 13-37, see p. 21). Seasonal variations in the incidence of ophthalmia, of which three types were noted, were also observed by Desgenettes, chief physican to Napoleon's army in Egypt (Bruant, 'Account of the prevailing ophthalmia of Egypt', in Memoirs relative to Egypt, London, Phillips, 1800, pp. 110-18).

114 MacCallan found that after four years of school the most contagious stages of trachoma during which complications endangering the sight are most likely to occur fall to about 10 per cent (A. F. MacCallan, 'The epidemiology of trachoma', Br. J. Ophthalm., 1931, 15: 369-411, see p. 380); cf. R. P. Wilson, Ann. Rep. Giza Mem. ophthalm. Lab., 1929, 4: 77. B. R. Jones, 'The prevention of blindness from trachoma', Trans. Ophthalm. Soc. UK, 1975, 95: 16-33, fig. 4 shows the prevalence of active stages of trachoma peaking at 2-3 years of age and then falling.

${ }^{115}$ H. A. P. C. Oomen, D. S. McLaren, and H. Escapini, 'Epidemiology and public health aspects of hypovitaminosis A', Trop. geogr. Med., 1964, 4: 271-315; cf. Brunner, op. cit., note 105 above. 


\section{R. L. Miller}

supplied with excellent rations, and a diet including deliveries of cereal, beer, salad greens, meat, oil, fat, and fish ${ }^{116}$ would make this expression of vitamin A deficiency unlikely.

When Gunn published examples of the blindness steles from Deir el Medina in the collection of the British Museum, he raised the possibility that there may have been specific occupational hazards involved: "Are we to infer that the decoration of the dark tomb-chambers of the Necropolis . . . was specially detrimental to the eyesight?".117 There is a form of eye trouble which could have affected the workmen of Deir el Medina more than ordinary Egyptians, one related to the amount of time the tomb workers would have spent in poorly lit, underground work while cutting out and decorating the king's tomb. Nystagmus is an occupational disease affecting people such as miners, ceiling plasterers, or even a violinist obliged to work for years in dimly lit environments. ${ }^{118}$ The symptoms of nystagmus include a slowness in dark adaptation; men complain that they take longer than usual to become accustomed to the darkness they work in, and of photophobia, in connection with the lamps of other miners in the pit or intolerance to daylight on coming up. Rapid oscillatory movements of the eyeball also occur. Although some miners become tolerant of this oscillation and are able to compensate for it, others complain of objects spinning about, and greatly increased levels of anxiety are also typical. ${ }^{119}$

Miner's nystagmus is primarily a disease of the middle-aged or elderly miner, and may take 10 to 25 years to develop. ${ }^{120}$ Figures for its incidence vary greatly. Nystagmus affected 1 in 225 miners in Britain in 1922; ${ }^{121} 30$ years earlier five men out of an underground workforce of 300 at one candle-lit pit were off work because of nystagmus. ${ }^{122}$ If conditions of lighting in this latter type of mining operation were similar to those experienced by the workmen in the Valley of the Kings, where lighting was provided by wicks greased with fat and oil, ${ }^{123}$ nystagmus could have occurred in as many as 1 in 60 of the tomb workmen from Deir el Medina, given the poor lighting under which they would have had to work on details of sculpture, painting, and script.

The formulae recorded on the eye steles from Deir el Medina frequently include complaints about seeing darkness by day, and requests to see the light which the divinity had created or to see the sun, which might refer in some cases to an inability to tolerate daylight. ${ }^{124}$ However these symptoms were only temporary. There would have

116 Janssen, op. cit., note 6 above, pp. 112-32, 330-69, 455-93.

117 Gunn, op. cit., note 109 above, p. 89.

118 Hunter, op. cit., note 54 above, pp. 835-6.

119 Ibid., pp. 836-9.

120 Ibid., p. 837.

121 Ibid., p. 841.

122 S. Snell, Miners' nystagmus, Bristol, John Wright, 1892, p. 23.

123 J. Cerný, The Valley of the Kings, Cairo, Institut Français d'Archéologie Orientale du Caire, 1973, pp. 43-54.

${ }_{124}$ Gunn, op. cit., note 109 above; Tosi and Roccati, op. cit., note 109 above, p. 230; dimming of vision was a major symptom singled out in an early study of nystagmus (C. B. Taylor, 'Observations on miners' nystagmus, a new disease', Lancet, 1875, i: 821-2). One case, a 44-year-old miner, came to Taylor "complaining of dimness of vision so great that he had been obliged to give up his work. He said that on fixing his lamp in order to break up coal the light began to dance about; he turned giddy; objects seemed enveloped in mist; and he was obliged to desist" (ibid., p. 822). The distress of a tomb painter on seeing the images of the divinities he was working on enveloped in mist and lights dancing about would be considerable. 
been no point to the steles' recurrent formula requesting the return of normal eye function if actual blindness had occurred. ${ }^{125}$ While the question of the existence of miner's nystagmus among workmen at Deir el Medina must remain open, the concentration of this class of stele among a group of workmen exposed to the kind of working environment where nystagmus could develop suggests that this was among the forms of eye pathology that they experienced. Work on royal tombs was only intensive for relatively short periods of time. Although nystagmus might have developed in susceptible subjects during these periods of underground work, they would have had a good opportunity for recovery during later, less intensive stints of work when they could spend more time above ground. And since the symptoms of nystagmus can quickly disappear after the worker shifts to daylight work, ${ }^{126}$ the few days spent above ground preparing and decorating the steles recording their prayers may have sometimes achieved the desired result, although a period of recuperation may have been necessary to recover some sight before this could be undertaken.

\section{SINW AND FIRST AID}

Given the risks of injury from rock fall in any mining or quarrying project, ${ }^{127}$ it is likely that one of the functions of the physicians employed among the necropolis workmen would have been to provide first aid in case of accidents. Cutting tomb shafts into the strata of Theban limestone and flints found in the Valley of the Kings would have exposed the necropolis workmen to the risk of injuries from fallen rocks faced by miners in later times. Many of these would probably have been the kind of traumatic head injury which make up nearly half of the cases discussed in the Edwin Smith surgical papyrus. ${ }^{128}$ In the nineteenth century, head injuries were common among Cornish tin and copper miners. As one physician in the area noted at the time, "Although the miners' heads are protected by a hard hat, made from felt saturated with shellac ... stones occasionally fall from the sides of a shaft or the roof of a level, and the head is most likely to receive the blow". ${ }^{129}$ As a result, surgeons in Redruth and Camborne developed considerable expertise in the treatment of skull fractures. ${ }^{130}$

We may even have an example of the kind of first aid manual based on extensive practical experience which sinw employed on government building, quarrying, and tomb cutting projects would have found useful, the Edwin Smith Papyrus. ${ }^{131}$ While the author of this text may have had experience of military medicine where serious head

\footnotetext{
${ }^{125}$ Gunn, op. cit., note 109 above: Clère, op. cit., note 109 above; Tosi and Roccati, op. cit., note 109 above, stele nos. 50046, 50050-50052. Blindness never results from nystagmus, despite the distress it causes to many of those suffering from it, who fear they are going blind (Hunter, op. cit., note 54 above, p. 840). 126 Ibid.

${ }^{127}$ A nineteenth-century survey found that among 15 to 54 -year-olds, the rate of deaths that could be attributed to accidental injury among miners over a five-year period (1849-53) reached 7.5-8.8/1000 among Staffordshire miners, 2.2-3.7/1000 among Durham miners, and 1.9-2.4/1000 among Cornish miners, compared with national rates of 0.9-1.4/1000 over the same five-year period (C. Barham, 'The diseases of Cornish miners', Br. med. J., 1871, ii: 253-5).

${ }_{128}$ Breasted, op. cit., note 4 above, vol. 1, Cases 1-22, pp. 78-297.

${ }^{129}$ R. S. Hudson, 'On the use of the trephine in depressed fractures of the skull', Br. med. J., 1877, ii: 75-6, see p. 76.

130 Ibid., pp. 75-76.

131 Breasted, op. cit., note 4 above.
} 


\section{R. L. Miller}

injuries would also have been frequent, ${ }^{132}$ the text of the copy which has been preserved was found near Thebes, perhaps near Deir el Medina itself, ${ }^{133}$ and would not have been out of place among the manuscripts later found in private ownership in the village. ${ }^{134}$ Papyrus Edwin Smith is, however, much earlier than the papyri found in Deir el Medina, and is no later than the early Eighteenth Dynasty, before the village was firmly established. It can certainly not be assumed that it was owned by a craftsman, although it represents a genre that could have been useful in treating work-related accidents.

When accidents or injuries did occur, the clear presentation of the case histories described in Papyrus Edwin Smith would have been helpful in enabling physicians employed among the workmen on the necropolis to make their own assessment of the chances for their fellow workers' recovery. To take only one example, Case 8 describes hemiparesis following a compound fracture of the skull, with no visible external injury:

If thou examinest a man having a smash of his skull, under the skin of his head, while there is nothing at all upon it, thou should palpate his wound. Shouldst thou find that there is a swelling protruding on the outside of that smash which is in his skull, while his eye is askew because of it, on the side of him having that injury which is in his skull; (and) he walks shuffling with his sole, on the side of him having that injury which is in his skull . . . Thou shouldst account him one whom something from outside has smitten, as one who does not release the head of his shoulder-fork ... while he discharges blood from both his nostrils (and) from both his ears, (and) he suffers with stiffness in his neck. An ailment not to be treated. ${ }^{135}$

Medical treatment of head injury must still take account of possible severe consequences and uncertain prognosis for recovery, ${ }^{136}$ and it is interesting to see that the Egyptian sinw made less optimistic noises about the efficacy of the means of treatment at their disposal than some eighteenth- and nineteenth-century

\footnotetext{
132 The vocabulary used to characterize a number of the head injuries referred to in Papyrus Edwin Smith suggests that they may have occurred in warfare, and head wounds from weapons are known to have been frequent from ancient Egyptian literary sources and skeletal material (ibid., pp. xiv, 43, 82, 140, 156, pls. 1-2, 7-8). Head injuries may also have occurred following disputes among workmen, especially during summer months when water and tempers could be short. The records of a judicial proceeding among a group of workmen at Deir el Medina include one concerning a workman convicted to rock breaking for assaulting three people: "Year 6, third month of summer, 26th day. Putting 'Onakhte to cut stones in the Place of Truth for having struck the head of Djaydjay, Pidhu and Mentpha'py" (A. Massart, 'The Egyptian Geneva Papyrus MAH 15274', Mitt. Deutsch. Arch. Inst. Abt. Kairo, 1957, 15: 172-85, see pp. 182-3, pl. 38, vs. III). Corvee labour and government construction and quarrying projects in pharaonic Egypt would often have brought together workers from different areas, which would also have led to disputes where head injuries could have been common, and it is interesting that one of the names involved in this dispute, Pidhu, means "the man from the Delta" (ibid., p. 183).

${ }^{133}$ According to Breasted, it is possible that the Edwin Smith Papyrus and the Ebers Papyrus were both found in a tomb at Thebes around the middle of the nineteenth century (op. cit., note 4 above, p. 25), perhaps near Deir el Medina, where the medical papyrus purchased by Harris was discovered at about the same time in a 20 -foot deep shaft (ibid., p. 25).

134 Pestman, op. cit., note 75 above.

135 Translation by Breasted, op. cit., note 4 above, vol. 1, pp. 203-6.

136 D. R. Vogenthaler, 'An overview of head injury: its consequences and rehabilitation', Brain Injury, 1987, 1: 113-27; H. S. Levin, H. E. Gary, and H. E. Eisenberg, 'Duration of impaired consciousness in relation to side of lesion after severe head injury', Lancet, 1989, i: 1001-3.
} 


\section{Necropolis workmen in New Kingdom Egypt}

physicians. ${ }^{137}$ While Papyrus Edwin Smith is described by Breasted as a "surgical" papyrus, ${ }^{138}$ it is noteworthy that surgery is not recommended for the head injuries which occurred, although the person attending the injured person is given an idea of the expected outcome, and the limited range of treatment possible. ${ }^{139}$

\section{CONCLUSION}

The discovery that ordinary necropolis workmen during the New Kingdom were literate and possessed medical texts themselves opens new perspectives on the history of medicine in pharaonic Egypt. A rich tradition of popular medicine with a strong religious and magical component formed the basis of the patients' perception of their ills and the treatment they received. While $\sin w$ were sometimes employed as tomb workers, their role as physician is documented primarily in the formulation of medicines, although it is likely that they were able to provide incantations and first aid as well. The recognition and treatment of specifically work-related illnesses and injuries may have drawn on traditions of administration and recording of corvee labour, and there appears also to be a genre of literary and artistic representation which depicted occupational hazards and disabilities and has a strong palaeoepidemiological component.

The study of occupational disease and epidemiology in pharaonic Egypt is still in its early stages; further work could deal with aspects of the textual, archaeological, and artistic records which are beyond the scope of this article. However, there is one major absence among the diseases related to the activities of the necropolis workmen that are suggested by the texts or monuments. While silicosis or fibrosis could have affected the lungs of prisoners condemned to hammer granite and flint, ${ }^{140}$ cutting tombs into the limestone strata of the Valley of the Kings would probably not have caused severe

${ }^{137}$ P. Pott, 'Injuries of the head from external violence', in Chirurgical works, 3 vols., London, Johnson, 1790, vol. 1, pp. 3-270; Hudson, op. cit., note 129 above, p. 76; see also review by C. A. Ballance, A glimpse into the history of the surgery of the brain, London, Macmillan, 1922, pp. 58-79.

${ }^{138}$ Breasted, op. cit., note 4 above.

139 A high mortality was also expected from head wounds and accidents involving concussion in the Iliad (M. D. Grmek, Les maladies à l'aube de la civilisation occidentale, Paris, Payot, 1983, pp. 53-4 and 54 n. 79). Here, too, surgery was not an option.

${ }^{140}$ It has been suggested that the granite dust found in the lungs of a New Kingdom weaver, Nakht, may have been the result of his being sentenced to hammering on granite monuments (N. B. Millet, 'The archaeologist's view-in the museum', in G. D. Hart (ed.), Disease in ancient man, Toronto, Clarke Irwin, 1983, pp. 21-6, see pp. 24-5), like the hot-headed workman sentenced to hammering stone after assaulting three colleagues (Massart, op. cit., note 132 above, pp. 182-3). Radiological evidence of granite workers' fibrosis was found in 17 per cent of workers in the industry in one study cited by Hunter (op. cit., note 54 above, p. 958), with clinical signs of fibrosis in 53 per cent of the workmen (ibid.). Hammering granite, quartzite, and diorite would thus have been a high-risk undertaking, whose rough stages would have been understandably delegated to the sort of poorly housed-penal?-workforce crowded into the irregular buildings found around the sculptors' workshops at Amarna, where stone hammer fragments are still found on the surface. $N b-n f r$, a draughtsman in the royal tomb convicted of an offence, was sentenced by a court of his peers to being beaten, branded, and having to "cut stones in the Place of Truth" (khkhm $m t-M \bar{a} ' t)$, which Janssen suggests may have meant hammering flint near the tombs, where New Kingdom scatters of flintworking are found on the surface (J. J. Janssen, 'The mission of the scribe Pesiūr (O. Berlin 12654)', in Demaree and Janssen (eds.), op. cit., note 75 above, pp. 133-47, see pp. 138-9 n. p.). Silicosis has been associated with flintworking and grindstone cutting, and the dust in Nakht's lung would be consistent with the manufacture of the quartzite and granite grinding slabs using by ordinary households in New Kingdom Egypt (cf. A. B. Shaw, 'Knappers' rot: silicosis in East Anglian flint-knappers', Med. Hist., 1981, 25: 151-68; 
long-term respiratory problems. Dusts of calcium compounds such as the limestone there, or that used to build the pyramids are harmless to the lungs of workers even in occupations constantly exposed to them. ${ }^{141}$ Thus some form of eye disease, perhaps miners' nystagmus, together with mining and chiselling accidents, were among the few identifiable occupational diseases or risks the necropolis workmen would have been exposed to more than their contemporaries in other occupations.

see also D. A. Warrell et al., 'Silicosis among grindstone cutters in the north of Nigeria', Thorax, 1975, 30: 389-98). Silicosis does not affect modern experimental knappers, and would probably not have affected people during short-term stints of breaking stones. However a risk of silicosis could perhaps have been associated with the production of raw material for faience if the angular silicon dioxide fragments characteristic of some New Kingdom faience wares were the result of deliberately crushing flint to get a better quartz raw material than would have been available from sand, which would have had salts and organic matter not found in crushed flint, quartz, and quartzite dust. As such organic matter would have tended to give off carbon dioxide during firing, the smooth surface of faience would have been blown by bubbles and blebs unless absolutely pure raw materials were employed. The labour-intensive methods needed would be consistent with ancient Egyptian industrial practice and the efficient recycling of waste materials characteristic of its technological organization.

${ }^{141}$ Hunter, op. cit., note 54 above, p. 933. 